\title{
Nest site characteristics of cavity-nesting birds on a small island, in Haida Gwaii, British Columbia, Canada
}

\author{
Neil G. Pilgrim ${ }^{1, *}$, Johnna L. Smith ${ }^{1,2}$, Keith Moore ${ }^{1}$, and Anthony J. Gaston ${ }^{1}$ \\ ${ }^{1}$ Laskeek Bay Conservation Society, P.O. Box 867, Queen Charlotte City, British Columbia V0T 1S0 Canada \\ ${ }^{2}$ Nature United, 366 Adelaide Street East, Suite 331, Toronto, Ontario M5A 3X9 Canada \\ *Corresponding author: biologist@laskeekbay.org
}

Pilgrim, N.G., J.L. Smith, K. Moore, and A.J. Gaston. 2019. Nest site characteristics of cavity-nesting birds on a small island, in Haida Gwaii, British Columbia, Canada. Canadian Field-Naturalist 133(4): 352-363. https://doi.org/10.22621/cfn. v133i4.2277

\begin{abstract}
Many studies of cavity-nesting birds in North America are conducted in large continental forests and much less is known about them in island ecosystems. We describe a 29 -year study of tree species, nest site characteristics, and fledge dates of cavity-nesting birds on a small island in Haida Gwaii, British Columbia (BC). Seven cavity-nesting bird species were documented on East Limestone Island and 463 nests were found in 173 different trees. Nest trees were significantly taller and had a greater diameter than a random sample of snags. Tree height did not differ among bird species but diameter at breast height was larger for trees used by Brown Creeper (Certhia americana) than for other species. Cavity-nesters selected tree decay classes 2-7 (all dead/near dead [snags]), with 85\% in decay class 4 (35\%) or 5 (50\%), similar to the random snag sample (class 4, 32\%; class 5, 42\%). Cavity height ranged from 2.6 to $44.9 \mathrm{~m}$ and for all species, except Brown Creeper, the mean nest height was $>60 \%$ of the mean tree height. Nest heights were generally greater than observed elsewhere in BC. Nest cavity orientation was random except for Red-breasted Sapsuckers (Sphyrapicus ruber), for which only 13\% of the cavity entrances faced southeast. Median fledging dates ranged from 7 June (Chestnut-backed Chickadee [Poecile rufescens]) to 28 June (Northern Flicker [Colaptes auratus]). Estimated median dates of clutch completion were similar for all species. Our results show that large snags provide habitat for a high diversity of cavity-nesting birds on Haida Gwaii.
\end{abstract}

Key words: Wildlife trees; cavity-nesters; excavators; nest site; timing of breeding

\section{Introduction}

Dead and dying trees are essential for creating high quality nest sites for cavity-nesting birds ( $\mathrm{Li}$ and Martin 1991) and primary excavators (those species that normally excavate new nest sites each year) are essential to many secondary species in providing the necessary conditions for them to nest or find shelter (Aitken and Martin 2007). Many factors can contribute to nest-site quality including tree height, nest height, nest-hole orientation, and the state of tree decay (McClelland and Frissell 1975; Inouye 1976). The selection of a nest tree and characteristics of nest sites are known to contribute to the reproductive success of cavity-nesters by affording protection for the breeder and their offspring from predators and improved microclimate in the nest cavity (Von Haartman 1957; Wesołowski 2002; Maziarz and Wesołowski 2013).

Cavity-nesting birds can be divided into three groups related to how they acquire their cavity: (1) primary cavity-nesters excavate their own holes in live or dead trees and typically excavate a new hole each year, (2) secondary cavity-nesters use holes ex- cavated by other species (usually primary cavity nesters), use a naturally occurring hole and may re-use nests, and (3) weak cavity-nesters either make their own hole in a heavily decaying tree, nest in a cavity excavated by another species, or expand a naturally occurring hole. A bark nester, Brown Creeper (Certhia americana), has also been included in this paper, though it mainly nests under loose bark (Davis 1978).

Nest site characteristics vary among and within bird species by geographic location and forest type (Scott et al. 1977; Newton 1994). Characteristics of cavity-nests most often reported include nest tree species, height, diameter, state of decay (or decay class), height of the nest site above the ground, and the cardinal direction of the cavity entrance. Most studies examined these characteristics for continental forests (e.g., Carlson et al. 1998; Martin et al. 2004; Vaillancourt et al. 2008), usually in relation to forest management guidelines in order to maintain stand structure to support cavity-nesters (e.g., Steeger and Dulisse 2002). Few studies have examined these

A contribution towards the cost of this publication has been provided by the Thomas Manning Memorial Fund of the Ottawa Field-Naturalists' Club. 
characteristics in small island ecosystems. These may differ from continental ecosystems in having fewer suitable nest sites due to the limited forest area available and/or having more pronounced edge to interior effects, thus increasing risks from predation.

The purpose of our study was to identify nest site characteristics of cavities as well as timing of breeding for all regularly-occurring cavity-nesting species on a small island in Haida Gwaii. Nest site characteristics were measured within the island's mature forest ecosystem by researchers and citizen scientists of the Laskeek Bay Conservation Society (http:// www.laskeekbay.org), a local non-profit organization founded in 1990, with a well-established annual field program. We examined characteristics of nest trees selected by cavity-nesters and compared them with a random selection of available trees. We also compare the results from our island study to other ecosystems and discuss the likely selection pressures governing nest site choice in this ecosystem.

\section{Study Area}

Data were collected on East Limestone Island, Haida Gwaii, British Columbia (BC), Canada $\left(52.90747^{\circ} \mathrm{N}\right.$, $\left.131.613^{\circ} \mathrm{W}\right)$, a 48 ha island located in Laskeek Bay in the K'unna Gwaay heritage site/conservancy. It is adjacent to the southeast tip of Louise Island (27200 ha) and is separated from it by only $400 \mathrm{~m}$ at the closest point. The island is mostly flat, or gently sloping, with the highest point of elevation being $65 \mathrm{~m}$ on the south ridge. Elevation gradients are most prominent along the east and west coasts where multiple coves lead to the sea via steep slopes. The northern coast of the island is the site of a large cove that encompasses most of that coast.

East Limestone Island is in the Coastal Western Hemlock Zone, wet Hypermaritime subzone, a BC biogeoclimatic category characterized by cool winters and mild, cool, wet summers with periodic dry warm spells (Banner et al. 2014). Strong winds are common and form an important climatic feature. Rainfall can exceed $1000 \mathrm{~mm}$ annually. The forest is primarily dominated by mature Sitka Spruce (Picea sitchensis (Bongard) Carrière), Western Hemlock (Tsuga heterophylla (Rafinesque) Sargent), and Western Red Cedar (Thuja plicata Donn ex D. Don). Red Alder (Alnus rubra Bongard), Pacific Crabapple (Malus fusca (Rafinesque) C.K. Schneider), Sitka Alder (Alnus alnobetula ssp. sinuata (Regal) Raus), and Scouler's Willow (Salix scouleriana Barratt ex Hooker) are present along the shoreline and in a few places within the interior forest. The understorey is sparse due to shade from the mature trees and intense browsing by the invasive Black-tailed Deer (Odocoileus hemionus; Stockton et al. 2005).
Although shrubs are sparse, they occur throughout the island and include Vaccinium species (Red Huckleberry [Vaccinium parvifolium Smith], Ovalleaved Blueberry [Vaccinium ovalifolium Smith]), Salal (Gaultheria shallon Pursh), and Red Elderberry (Sambucus racemosa L.).

The forest has not been commercially logged and most trees have been estimated to be more than 100 years old (K.M. pers. obs.). Like most temperate coastal old-growth systems, wind is a major factor for disturbance on the island, with windthrow the most common reason for gap creation and tree mortality (Pojar and MacKinnon 1994), in part due to shallow soils and high edge-interior effects. In 2010, a major windstorm hit Laskeek Bay and $\sim 50 \%$ of the forest on East Limestone Island was blown down, resulting in high mortality for mature Western Hemlock and Sitka Spruce.

\section{Methods}

\section{Nest location and monitoring}

Between 1991 and 2018, staff and volunteers of the Laskeek Bay Conservation Society searched for and recorded cavity-nests on East Limestone Island. Observations were made of the tree characteristics, the nest cavities, and the species that occupied them. This comprised the "wildlife tree monitoring program", a citizen science effort involving numerous staff and volunteers each year from 1990 to 2018. Observations were made throughout May and June in all years and up to 9 July in all but five years (19901992, 2002, 2003, and 2011). From the beginning of the monitoring program, trees containing active nests were tagged with unique numbers and mapped. In 1990, observations were incidental to other work. The next year a systematic methodology to detect occupied breeding sites was designed and occurred annually using a written protocol. From 1991 to 1995, nests were located by listening for begging chicks during the nestling period. From 1996 onwards, all trees used at least once during the previous five years were included in that year's sample of nest trees and observed three times for $30 \mathrm{~min}$ in late April or May during the nest building, egg laying, and incubation phases of breeding. The observations were made, generally, within a few days of each other by one or two observers with binoculars situated at least $15 \mathrm{~m}$ from the nest tree. If no activity was observed after these three visits the tree was considered inactive for that season. If activity was observed, the tree was considered active and checked for 30 min every three days during June for evidence of breeding activity (e.g., adults feeding nestlings or chicks calling). Once chicks were heard calling, nests were checked every two days for $30 \mathrm{~min}$ (weather permitting) to deter- 
mine when chick calling ceased, assumed to be a sign that the nestlings had fledged. Up to three times per season (late-May to mid-July) a survey of the entire 45 ha island was conducted to locate any new nest sites; the island was divided into four quadrants and four to six observers would spend several hours moving slowly throughout them, watching and listening for cavity nesting birds. Once active nests were confirmed and chicks were being fed, all the remaining wildlife trees that had been surveyed earlier in the season were visited again and monitored for $10 \mathrm{~min}$ to confirm vacancy-ensuring that no active nests had been missed. This protocol was thought to have a very high chance of success for the primary cavity nesters, as all have young that call loudly from the nest site and in every year, four to six observers were present on the island throughout the nesting season. However, our inventory was not likely to be complete for the other species, especially Brown Creeper, which has rather quiet young. All new nest trees were numbered, added to the monitored nest inventory, nest site characteristics measured and recorded, and location mapped. At the end of each season, any nest tree that had been inactive for five seasons was removed from the "active" inventory.

Fledging date was assigned to the average of the last date when chicks were seen or heard and the first date with no sound or visuals. Sightings of fledglings out of the nest were also used as an indication of fledging date. For species with 10 or more records of active nest sites on the island, the dates of the onset of incubation were estimated by taking the estimated date of fledging from the field surveys and subtracting incubation and fledging periods provided by the relevant species accounts in the Birds of North America (https://birdsna.org/Species-Account/bna/). Durations of incubation and fledging periods applied are given in Appendix 1.

Multiple characteristics were noted for each active nest tree: bird species, tree species, total tree height (m), percent cover bark (main stem), tree classification (including number of bracket fungi; see Guy and Manning 1995), nest cavity entrance height, tree diameter at breast height (dbh), and nest cavity orientation. These characteristics were recorded when a hole was first discovered and subsequently if any changes occurred (e.g., tree height). In this paper, we use the BC Tree Classification System (Guy and Manning 1995) to determine the current level of decay of each tree when first used. The BC Tree Classification System has nine categories, ranging from 1 -live/healthy to 9-debris (Figure 1). The term snag refers to a standing dead or dying tree. British Columbia's Tree Classification class 2 is live/unhealthy and, in this paper, will be referred to as a snag. All the characteristics listed in BC Tree Classification System (Figure 1) were used to determine what decay class a snag was considered to be. If characteristics of different decay classes were found in one snag, the snag was classified according to the maximum number of characteristics.

\section{Random sample of available nest trees}

In July 2004, an island-wide survey was carried out to obtain a random sample of all possible trees available for cavity-nesters in decay class 2 or higher. We selected random trees at $50 \mathrm{~m}$ intervals along the two main trails on the island. At each interval, we took a $90^{\circ}$ bearing, perpendicular to the trail, and

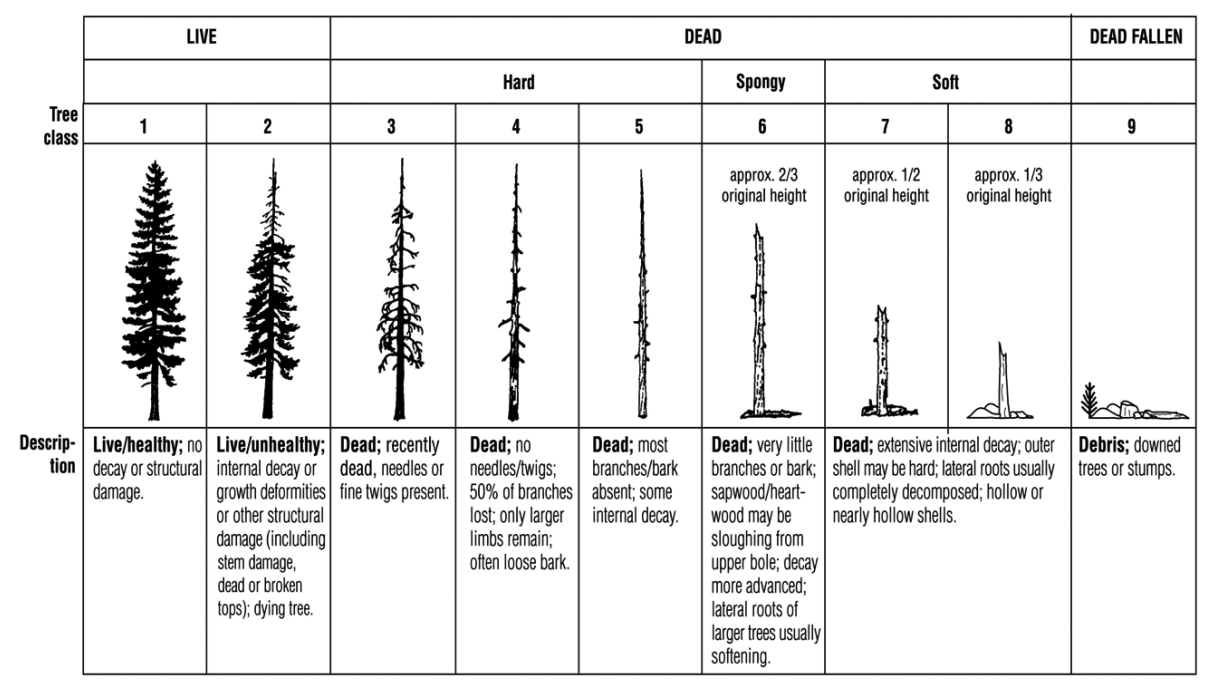

Figure 1. British Columbia’s Tree Classification System (Guy and Manning 1995). 
laid out a $20 \mathrm{~m}$ transect, measuring all dead/near dead (decay class 2-8) trees that fell within $\sim 5 \mathrm{~m}$ of either side of the transect. The same characteristics were recorded for these trees that were recorded for the occupied nest trees.

\section{Statistical analysis}

Five cavity-nesting species for which sample sizes were more than five were used in statistical comparisons: Red-breasted Sapsucker (Sphyrapicus ruber), Hairy Woodpecker (Dryobates villosus), Northern Flicker (Colaptes auratus), Chestnut-backed Chickadee (Poecile rufescens), and Brown Creeper. The first three species are primary cavity-nesters and the fourth and fifth are, respectively, a weak excavator and a bark nester. For the analysis of tree characteristics used by cavity-nesters - tree height, tree species, $\mathrm{dbh}$, and state of decay - we used the characteristics as described the first time that a tree was found in use by each bird species, regardless of how many years a nest tree was active. When analyzing individual nest height and orientation, all nests across all years were analyzed.

Most statistical analysis were conducted using PAST3 (Hammer et al. 2001) for Mac OSX: analysis of variance (ANOVA) with Tukey's pairwise tests were used to compare tree height, nest height, and dbh among the cavity-nesting species. A two-sample $t$-test was used to compare the trees used by cavitynesting species to a random sample of trees of similar decay class for tree height and nest height. Statistical program R version 3.4.3 (R Core Team 2017) was used to conduct a Rayleigh test of uniformity to compare nest hole orientations among species. Means are given $\pm 1 \mathrm{SD}$. Some data were not recorded for some nests, so that sample sizes are not the same for all analyses.

\section{Results}

During our study, the island supported seven cavity nesting birds: three primary cavity nesters: Redbreasted Sapsucker, Hairy Woodpecker, and Northern Flicker; two weak excavators: Chestnut-backed Chickadee and Red-breasted Nuthatch (Sitta canadensis); a bark nester: Brown Creeper; and a secondary cavity nester: Northern Saw-whet Owl (Aegolius acadicus). A total of 463 nests were found in 173 different trees: Red-breasted Sapsucker $(n=344)$, Hairy Woodpecker (33), Northern Flicker (9), Chestnutbacked Chickadee (47), Red-breasted Nuthatch ( 9), Brown Creeper (19); and Northern Saw-whet Owl (2). The main excavator on the island was overwhelmingly Red-breasted Sapsucker, which occupied 74\% of the cavity nests found.

\section{Tree characteristics}

We located and tagged 173 trees used by cavitynesting birds between 1990 and 2018 (Table 1). Most of the cavity-bearing trees were Sitka Spruce $(60 \%)$ or Western Hemlock (32\%) with a small percentage of Red Alder (3\%) and Western Red Cedar (1\%), and a few of unknown identity, either because the species were missing in data records or the decay class did not allow species determination (4\%; Table 2).

TABLE 1. Mean, SD, minimum and maximum tree heights, and tree diameters of bark nesting (Brown Creeper [Certhia americana]) and cavity-nesting birds and random sample of snags on East Limestone Island, Haida Gwaii, from 1990 to 2018.

\begin{tabular}{|c|c|c|c|c|c|c|c|}
\hline & \multirow{2}{*}{$n$} & \multicolumn{3}{|c|}{ Tree height (m) } & \multicolumn{3}{|c|}{ Tree diameter $(\mathrm{dbh} ; \mathrm{cm})$} \\
\hline & & Mean & SD & Range & Mean & SD & Range \\
\hline $\begin{array}{l}\text { Red-breasted Sapsucker } \\
\text { (Sphyrapicus ruber) }\end{array}$ & 130 & 22.7 & 10.4 & $7.2-52.8$ & 104 & 40 & $40-260$ \\
\hline $\begin{array}{l}\text { Hairy Woodpecker } \\
\text { (Dryobates villosus) }\end{array}$ & 27 & 20.7 & 9.7 & $3.8-40.8$ & 93 & 32 & $50-200$ \\
\hline $\begin{array}{l}\text { Northern Flicker } \\
\text { (Colaptes auratus) }\end{array}$ & 8 & 19.7 & 6.0 & $14.1-32.8$ & 93 & 41 & $46-170$ \\
\hline $\begin{array}{l}\text { Chestnut-backed Chickadee } \\
\text { (Poecile rufescens) }\end{array}$ & 29 & 22.2 & 12.8 & $5.1-46.6$ & 119 & 57 & $31-240$ \\
\hline $\begin{array}{l}\text { Red-breasted Nuthatch } \\
\text { (Sitta canadensis) }\end{array}$ & 5 & 21.5 & 7.5 & $15.4-33.9$ & 104 & 32 & $68-154$ \\
\hline $\begin{array}{l}\text { Northern Saw-whet Owl } \\
\text { (Aegolius acadicus) }\end{array}$ & 2 & 12.6 & 3.6 & $10.0-15.1$ & 96 & 49 & $61-130$ \\
\hline $\begin{array}{l}\text { Brown Creeper } \\
\text { (Certhia americana) }\end{array}$ & 16 & 22.4 & 13.7 & $7.2-58.5$ & 133 & 54 & $54-260$ \\
\hline All cavity-bearing trees* & 173 & 21.7 & 11.1 & $3.8-58.5$ & 104 & 43 & $31-260$ \\
\hline Random selection of snags & 100 & 12.6 & 11.1 & $1.3-63.3$ & 62 & 46 & $11-229$ \\
\hline
\end{tabular}

*Total number of nest trees used throughout the study. These trees were used more than once by various bird species. 
TABLE 2. Percentages of tree species used by various cavity-nesting birds on East Limestone Island, Haida Gwaii.

\begin{tabular}{|c|c|c|c|c|c|}
\hline Species & $\begin{array}{c}\text { Sitka Spruce } \\
\text { (Picea } \\
\text { sitchensis) }\end{array}$ & $\begin{array}{c}\text { Western } \\
\text { Hemlock } \\
\text { (Tsuga } \\
\text { heterophylla) }\end{array}$ & $\begin{array}{l}\text { Red Alder } \\
(\text { Alnus rubra) }\end{array}$ & $\begin{array}{c}\text { Western Red } \\
\text { Cedar } \\
\text { (Thuja plicata) }\end{array}$ & Unknown \\
\hline $\begin{array}{l}\text { Red-breasted Sapsucker }(n=130) \\
\text { (Sphyrapicus ruber) }\end{array}$ & 56.9 & 36.9 & 1.5 & 0.0 & 4.6 \\
\hline $\begin{array}{l}\text { Hairy Woodpecker }(n=26) \\
(\text { Dryobates villosus })\end{array}$ & 65.4 & 34.6 & 0.0 & 0.0 & 3.9 \\
\hline $\begin{array}{l}\text { Northern Flicker }(n=8) \\
\text { (Colaptes auratus) }\end{array}$ & 75.0 & 12.5 & 12.5 & 0.0 & 0.0 \\
\hline $\begin{array}{l}\text { Chestnut-backed Chickadee }(n=29) \\
\text { (Poecile rufescens) }\end{array}$ & 79.3 & 17.2 & 3.5 & 0.0 & 0.0 \\
\hline $\begin{array}{l}\text { Red-breasted Nuthatch }(n=5) \\
\text { (Sitta canadensis) }\end{array}$ & 60.0 & 40.0 & 0.0 & 0.0 & 0.0 \\
\hline $\begin{array}{l}\text { Brown Creeper }(n=16) \\
(\text { Certhia americana })\end{array}$ & 75.0 & 18.8 & 0.0 & 6.3 & \\
\hline $\begin{array}{l}\text { Northern Saw-whet Owl }(n=2) \\
\text { (Aegolius acadicus) }\end{array}$ & 100.0 & 0.0 & 0.0 & 0.0 & 0.0 \\
\hline All cavity-bearing trees $(n=173)$ & 59.5 & 31.8 & 2.9 & 1.2 & 4.6 \\
\hline Random selection of snags $(n=100)$ & 64.0 & 31.0 & 4.0 & 1.0 & 0.0 \\
\hline
\end{tabular}

The percentage distribution of cavity trees was similar to the distribution of a random selection of snags throughout the island (Sitka Spruce $=64 \%$, Western Hemlock $=31 \%$, Red Alder $=4 \%$, Western Red Cedar $=1 \%$ ). Among cavity-nesting species with five or more active nest trees, use of Sitka Spruce ranged from 57 to $79 \%$, Western Hemlock from 13 to $40 \%$, Red Alder from 2 to $13 \%$, and Western Red Cedar from 1 to $6 \%$. There was no evidence of inter-species differences in nesting tree preference (Table 2).

The nest trees of Red-breasted Sapsucker, Hairy Woodpecker, Chestnut-backed Chickadee, and Brown Creeper were significantly taller and larger in diameter than a random sample of snags on the island (Table 3); Northern Flicker nest trees were taller but not significantly larger in diameter. Nest tree height did not differ significantly among the bird species (ANOVA $F_{4,206}=0.27, P=0.93$ ), but diameter was significantly different among species $\left(F_{4,204}=2.44\right.$, $P=0.04$ ), with Brown Creeper using trees with significantly larger diameter than Hairy Woodpecker (Tukey's pairwise: $P<0.05$ ). Height and diameter were positively correlated for both the active and the randomly selected snags (active: $r_{166}^{2}=0.37, P<0.001$; random $\left.r_{98}^{2}=0.31, P<0.01\right)$.

Cavity-nesters used trees in decay classes 2 through 7 and showed a strong preference for decay classes 4 and 5 (Table 4, Figure 2); 50\% of all active nest trees were in snags of decay class 5 and $35 \%$ were class 4 . Trees in classes $4(32 \%)$ and $5(42 \%)$ were also the most common in the randomly selected snag sample, but the proportion of snags in decay class 2 and 3

TABLE 3. Analyses comparing mean tree heights and diameters of nest trees to a random sample of snags $(n=100)$, East Limestone Island, Haida Gwaii.

\begin{tabular}{|c|c|c|c|c|c|c|}
\hline & \multirow{2}{*}{$n$} & \multicolumn{2}{|c|}{ Tree height (m) } & \multicolumn{2}{|c|}{ Tree diameter $(\mathrm{dbh} ; \mathrm{cm})$} & \multirow{2}{*}{$\frac{\text { Effect size }}{d^{*}}$} \\
\hline & & $t$ & $P$ & $t$ & $P$ & \\
\hline $\begin{array}{l}\text { Red-breasted Sapsucker } \\
\text { (Sphyrapicus ruber) }\end{array}$ & 126 & 7.0 & $<0.01$ & 7.1 & $<0.01$ & 2.94 \\
\hline $\begin{array}{l}\text { Hairy Woodpecker } \\
\text { (Dryobates villosus) }\end{array}$ & 27 & 3.4 & $<0.01$ & 3.2 & $<0.01$ & 2.88 \\
\hline $\begin{array}{l}\text { Northern Flicker } \\
\text { (Colaptes auratus) }\end{array}$ & 8 & 2.9 & 0.01 & 1.8 & 0.07 & 4.41 \\
\hline $\begin{array}{l}\text { Chestnut-backed Chickadee } \\
\text { (Poecile rufescens) }\end{array}$ & 29 & 3.9 & $<0.01$ & 5.4 & $<0.01$ & 2.32 \\
\hline $\begin{array}{l}\text { Brown Creeper } \\
\text { (Certhia americana) }\end{array}$ & 16 & 3.1 & $<0.01$ & 5.5 & $<0.01$ & 2.17 \\
\hline
\end{tabular}

*Cohen's $d$. 
TABLE 4. Decay classes of nest trees used by cavity-nesting birds and a random sample of snags on East Limestone Island, Haida Gwaii.

\begin{tabular}{lcccc}
\hline \hline & & \multicolumn{3}{c}{ Decay class } \\
\cline { 3 - 5 } Species & & Mean & SD & Range \\
\hline $\begin{array}{l}\text { Red-breasted Sapsucker } \\
\text { (Sphyrapicus ruber) }\end{array}$ & 124 & 4.6 & 0.7 & $2-6$ \\
$\begin{array}{l}\text { Hairy Woodpecker } \\
\text { (Dryobates villosus) }\end{array}$ & 26 & 4.8 & 0.9 & $2-6$ \\
$\begin{array}{l}\text { Northern Flicker } \\
\text { (Colaptes auratus) }\end{array}$ & 8 & 5.0 & 0.5 & $4-6$ \\
$\begin{array}{l}\text { Chestnut-backed Chickadee } \\
\text { (Poecile rufescens) }\end{array}$ & 27 & 4.7 & 0.7 & $3-6$ \\
$\begin{array}{l}\text { Red-breasted Nuthatch } \\
\text { (Sitta canadensis) }\end{array}$ & 5 & 5.0 & 0.7 & $4-6$ \\
$\begin{array}{l}\text { Brown Creeper } \\
\text { (Certhia americana) }\end{array}$ & 14 & 4.9 & 1.2 & $2-7$ \\
$\begin{array}{l}\text { Northern Saw-whet Owl } \\
\text { (Aegolius acadicus) }\end{array}$ & 2 & 4.5 & 0.7 & $4-5$ \\
$\begin{array}{l}\text { All cavity-bearing trees } \\
\begin{array}{l}\text { Random selection of snags } \\
\hline \hline\end{array}\end{array}$ & 163 & 4.7 & 0.8 & $2-7$ \\
\hline \hline
\end{tabular}

in the random sample significantly exceeded the proportion among used trees $(14 \%$ versus $3 \%$, respectively; contingency test, $\left.\chi_{2}^{2}=14.8, P<0.001\right)$. Hence, it appears that primary cavity excavators preferred trees in a more advanced state of decay than those in the random sample.

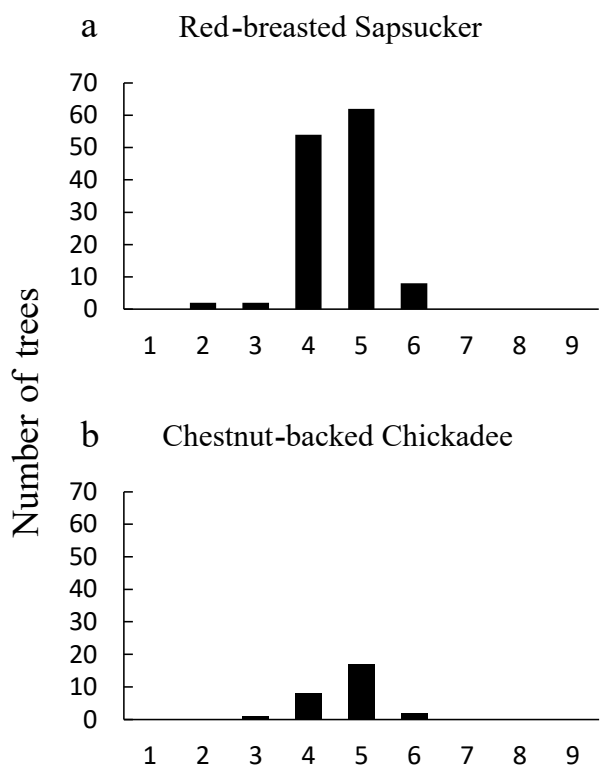

\section{Cavity characteristics}

Nest cavity heights ranged from 2.6 to $44.9 \mathrm{~m}$ from the base of the tree (Table 5). The Northern Flicker and Chestnut-backed Chickadee nests were, on average, the highest of the cavity-nesting species at 19.0 and $18.0 \mathrm{~m}$, respectively. The lowest nests were the Northern Saw-whet Owl, but only two nests were found during the study period. For all but Brown Creeper, the mean nest height was more than $60 \%$ of the mean tree height (Table 5); Brown Creeper mean nest height of $9.0 \pm 4.2 \mathrm{~m}$ was significantly lower than those of Red-breasted Sapsuckers, Hairy Woodpeckers, Northern Flickers, and Chestnutbacked Chickadees (Table 5).

Entrance orientation was not statistically significant for most species $(P>0.05$; Table 6$)$ with the exception of Red-breasted Sapsucker, for which fewer cavity openings than expected faced southeast $\left(91^{\circ}-\right.$ $180^{\circ} ; 13 \%$ of nests, $\left.P=0.01\right)$; however, sample sizes for other species were much smaller.

\section{Timing of breeding}

Breeding of cavity-nesting species ranged from 21 May to 9 July (Figure 3). For Red-breasted Sapsuckers, the most common cavity-nesting species on East Limestone Island, the annual median fledging dates spanned a 16-day period from 10 June. Chestnut-backed Chickadees were usually the first to fledge, with a median date of 7 June (Table 7). Northern Flicker had the latest median fledging
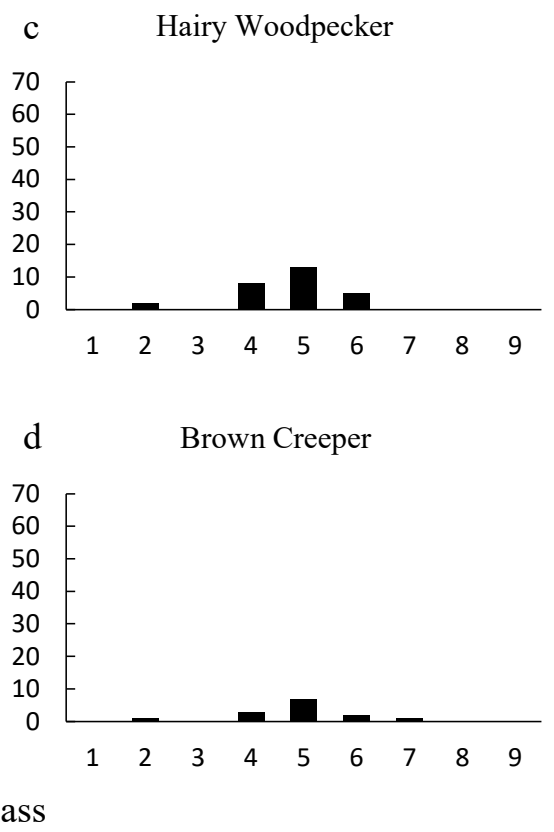

FIGURE 2. Distribution of snag classes used by different species of cavity-nesters on East Limestone Island, British Columbia, Canada (only species with $n>10$ ). 
TABLE 5. Nest heights of cavity-nesting species on East Limestone Islands, Haida Gwaii compared to provincial data (Campbell et al. 1990, 1997).

\begin{tabular}{|c|c|c|c|c|c|c|}
\hline \multirow[b]{2}{*}{ Species } & \multirow[b]{2}{*}{$n$} & \multicolumn{3}{|c|}{ Nest height (m) } & \multirow{2}{*}{$\begin{array}{c}\% \\
\text { Tree height }\end{array}$} & \multirow{2}{*}{$\begin{array}{c}\text { Birds of } \mathrm{BC} \\
\text { Min-max } \\
(>50 \% \text { range })^{*}\end{array}$} \\
\hline & & Mean & $\mathrm{SD}$ & Range & & \\
\hline $\begin{array}{l}\text { Red-breasted Sapsucker } \\
\text { (Sphyrapicus ruber) }\end{array}$ & 191 & $17.3^{*}$ & 7.7 & $3.8-44.9$ & 76.2 & $1.8-24(3-9)$ \\
\hline $\begin{array}{l}\text { Hairy Woodpecker } \\
\text { (Dryobates villosus) }\end{array}$ & 26 & $16.8^{*}$ & 8.2 & $5.4-32.8$ & 81.2 & $0.9-38(2-6)$ \\
\hline $\begin{array}{l}\text { Northern Flicker } \\
\text { (Colaptes auratus) }\end{array}$ & 7 & $19.0^{*}$ & 6.2 & $13.0-31.8$ & 96.4 & $0-27(<3)$ \\
\hline $\begin{array}{l}\text { Chestnut-backed Chickadee } \\
\text { (Poecile rufescens) }\end{array}$ & 26 & $18.0^{*}$ & 11.3 & $2.6-41.3$ & 81.1 & $0-26(2-6)$ \\
\hline $\begin{array}{l}\text { Red-breasted Nuthatch } \\
\text { (Sitta canadensis) }\end{array}$ & 5 & 13.4 & 0.8 & $12.7-14.5$ & 62.3 & $0.5-20(3-6)$ \\
\hline $\begin{array}{l}\text { Northern Saw-whet Owl } \\
\text { (Aegolius acadicus) }\end{array}$ & 2 & 9.3 & 0.4 & $9.0-9.6$ & 73.8 & $2.5-13.5$ \\
\hline $\begin{array}{l}\text { Brown Creeper } \\
\text { (Certhia americana) }\end{array}$ & 12 & $9.0^{\dagger}$ & 4.2 & $4.0-16.0$ & 40.2 & $0.2-15(2-6)$ \\
\hline
\end{tabular}

*Differs significantly from $\uparrow$ at $P<0.05$, Duncan Multiple Range Test.

Range within which greater than $50 \%$ of nests occurred.

TABLE 6. Number of cavity entrances facing northeast $\left(\mathrm{NE} ; 1^{\circ}-90^{\circ}\right)$, southeast (SE; $\left.91^{\circ}-180^{\circ}\right)$, southwest $\left(\mathrm{SW} ; 181^{\circ}-270^{\circ}\right)$, and northwest $\left(\mathrm{NW} ; 271^{\circ}-0^{\circ}\right)$ for four cavity-nesting species and $P$-values from a Rayleigh's test for uniformity for their nest cavity entrance orientation $(P<0.05$ for a Rayleigh's test indicates clustering).

\begin{tabular}{|c|c|c|c|c|c|}
\hline Species & $\mathrm{NE}$ & SE & SW & NW & $P$ \\
\hline $\begin{array}{l}\text { Red-breasted Sapsucker } \\
\text { (Sphyrapicus ruber) }\end{array}$ & 70 & 30 & 55 & 64 & 0.0077 \\
\hline $\begin{array}{l}\text { Hairy Woodpecker } \\
\text { (Dryobates villosus) }\end{array}$ & 6 & 3 & 4 & 3 & 0.5854 \\
\hline $\begin{array}{l}\text { Chestnut-backed Chickadee } \\
\text { (Poecile rufescens) }\end{array}$ & 2 & 1 & 4 & 2 & 0.5721 \\
\hline $\begin{array}{l}\text { Brown Creeper } \\
\text { (Certhia americana) }\end{array}$ & 2 & 3 & 4 & 1 & 0.7109 \\
\hline
\end{tabular}

date of 28 June. Median dates for the start of incubation were estimated to fall between 6-9 May for the four species with the largest sample sizes (Table 7). No evidence of second broods was found for any species, but four fledging dates for Chestnut-backed Chickadees fell after 21 June, two weeks after the long-term median in early June suggesting that some chickadees either laid very late or replaced earlier failed broods.

\section{Discussion}

Tree species

On East Limestone Island, cavity-nesting species primarily used spruce and hemlock trees for nesting and these were used in proportion to the available snags on the island; very few nests were in Red Alder and only Brown Creeper was found in Western Red Cedar. This was not surprising as most alders on the island were young, small diameter trees that were not very tall or in a state of decay. In other parts of $\mathrm{BC}$, deciduous trees are used by cavity-nesters, for example, Martin and Eadie (1999) and Martin et al. (2004) found $95 \%$ of cavities in the Cariboo-Chilcotin region of central interior $\mathrm{BC}$ were in Trembling Aspen (Populus tremuloides Michaux). The majority of these were created by Red-naped Sapsucker (Sphyrapicus nuchalis), Hairy Woodpecker, and Northern Flicker - a very similar primary excavator community to that on East Limestone Island.

\section{Tree height and cavity height}

Of the cavity-nesters with more than five active nest trees during the study period, the mean heights of nest trees were significantly higher than a random selection of snags, strongly suggesting that height is an important factor for the location of nest cavities on this island. In addition, all bird species except Brown Creeper created or used nest cavities in the top half of the tree. Nests were also generally much higher 


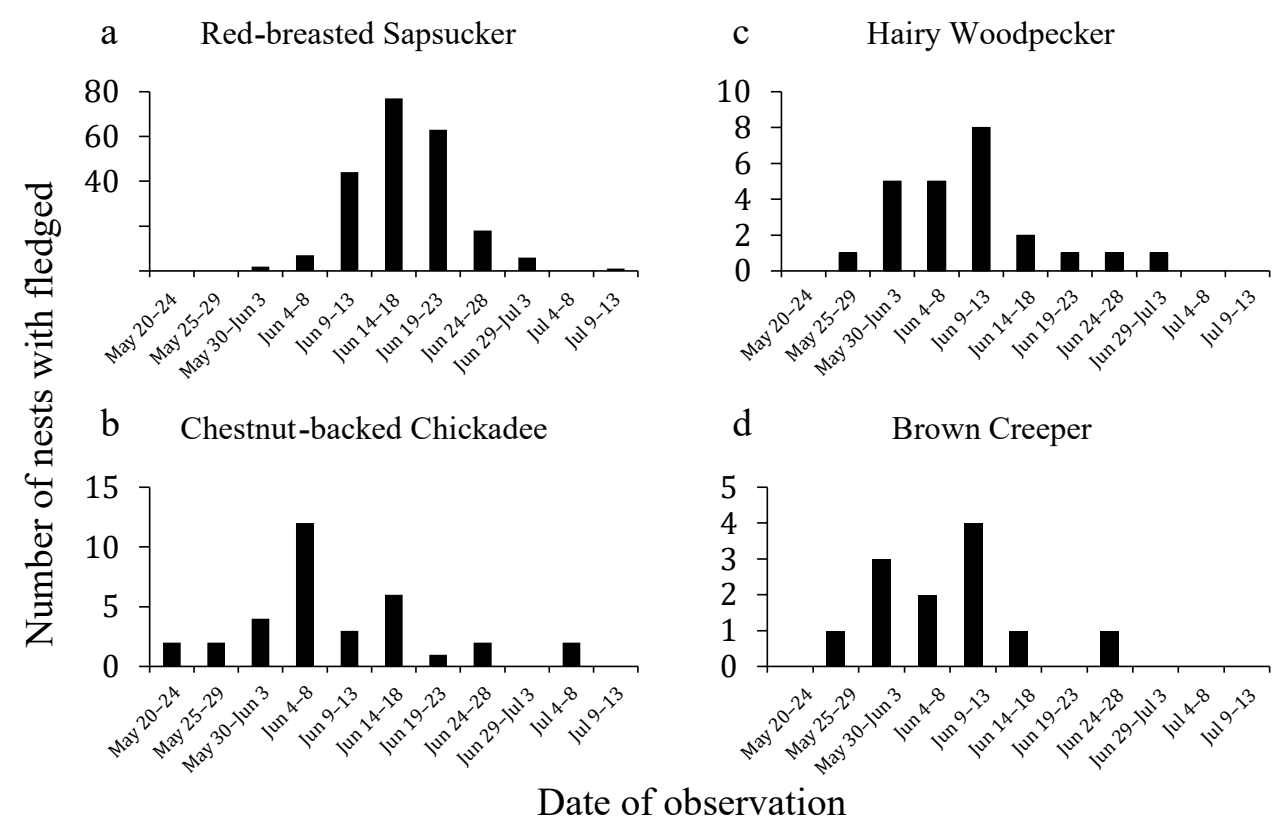

Figure 3. Observed fledging dates for cavity-nesting species on East Limestone Island, Haida Gwaii, British Columbia, Canada (1990-2018).

TABLE 7. Estimated median incubation and median and extreme fledging dates for cavity-nesters on East Limestone Island, Haida Gwaii, 1990-2018.

\begin{tabular}{|c|c|c|c|c|c|}
\hline Species & $n$ & $\begin{array}{l}\text { Estimated median } \\
\text { start of incubation }\end{array}$ & $\begin{array}{l}\text { Median date of } \\
\text { chick fledging }\end{array}$ & $\begin{array}{l}\text { Earliest fledging } \\
\text { date }\end{array}$ & $\begin{array}{l}\text { Latest fledging } \\
\text { date }\end{array}$ \\
\hline $\begin{array}{l}\text { Red-breasted Sapsucker } \\
\text { (Sphyrapicus ruber) }\end{array}$ & 219 & 7 May & 17 Jun & 1 Jun & $13 \mathrm{Jul}$ \\
\hline $\begin{array}{l}\text { Hairy Woodpecker } \\
\text { (Dryobates villosus) }\end{array}$ & 24 & 6 May & 10 Jun & 29 May & 30 Jun \\
\hline $\begin{array}{l}\text { Northern Flicker } \\
\text { (Colaptes auratus) }\end{array}$ & 5 & - & 28 Jun & 3 Jun & $5 \mathrm{Jul}$ \\
\hline $\begin{array}{l}\text { Chestnut-backed Chickadee } \\
\text { (Poecile rufescens) }\end{array}$ & 34 & 6 May & 7 Jun & 21 May & $1 \mathrm{Jul}$ \\
\hline $\begin{array}{l}\text { Red-breasted Nuthatch } \\
\text { (Sitta canadensis) }\end{array}$ & 3 & - & 12 Jun & 31 May & 16 Jun \\
\hline $\begin{array}{l}\text { Brown Creeper } \\
\text { (Certhia americana) }\end{array}$ & 10 & 9 May & 10 Jun & 28 May & 28 Jun \\
\hline
\end{tabular}

than those reported as 'typical' ( $>50 \%$ of nests) by Campbell et al. (1990, 1997), with mean nest heights on East Limestone Island more than twice the maximum of the typical range elsewhere for all species except Red-breasted Sapsucker and Brown Creeper.

The high nest sites on East Limestone Island could be a function of predation risk, with higher nests having lower risk (Kilham 1971; Nilsson 1984). The main potential nest predator of cavity-nesting birds was Red Squirrel (Tamiasciurus hudsonicus), while adults might have been susceptible to predation by Red-tailed Hawk (Buteo jamaicensis) and Sharp- shinned Hawk (Accipiter striatus), both of which occur on the island. Red Squirrel was introduced to Haida Gwaii in 1950 (Golumbia et al. 2008) and recorded on East Limestone Island by 1983. The species is an active predator on songbird nests in the area (Martin and Joron 2003). It was the only potential predator seen entering nest cavities on East Limestone Island (A.J.G. pers. obs.). The density of squirrels on the island fluctuates significantly among years (Martin et al. 2008) and is high in comparison with nearby larger islands that have other mammalian predators (e.g., Pine Marten [Martes americana], 
Black Bear [Ursus americanus]). One possible explanation for nest heights is that squirrels avoid tall trees denuded of leaves and branches to avoid avian predators, such as Red-tailed Hawk (visitors to East Limestone Island), or the resident Common Raven (Corvus corax). Furthermore, a nest near the top of a snag could result in less rainwater running into the cavity hole, compared with a cavity further down the tree (Conner 1975).

Brown Creeper nests lower than other species and build cryptic nests behind bark or rotten wood. Unlike other cavity-nesters, Brown Creeper nestlings do not call loudly from the nest when the parents are absent. Brown Creeper may depend on these cryptic habits to avoid detection and minimize predation. As a predator of small mammals and birds (Rasmussen et al. 2008), Northern Saw-whet Owl may be sufficiently intimidating to deter squirrels from entering their nests, which might explain why both the two owl nests found were much lower $(9.0$ $\mathrm{m}$ and $9.6 \mathrm{~m}$ ) than the average for other species. Only three nests of the Haida Gwaii subspecies of Sawwhet Owl (Aegolius acadicus brooksii) had been found by 2008 (Rasmussen et al. 2008), one of which was on East Limestone Island. Data are too limited to know whether low nest sites are characteristic of this subspecies. However, elsewhere in BC the species uses holes at similar heights to those found on East Limestone Island (Campbell et al. 1990).

\section{Tree diameter}

Red-breasted Sapsucker, Hairy Woodpecker, Chestnut-backed Chickadee, and Brown Creeper all used trees with significantly greater mean dbh than that of randomly selected snags (Table 3 ), a finding also made by Martin et al. (2004) in interior BC and by Raphael and White (1984) in the Sierra Nevada. Brown Creeper selected significantly larger tree diameters than those used by Hairy Woodpecker. Height and $\mathrm{dbh}$ are correlated so we cannot distinguish which has the greater influence of nest site choice. While height may confer protection from predation and better drainage, greater girth may allow for deeper nests or better thermal protection (O'Connor 1978; Van Balen 1984). In addition, a larger cavity size could increase space for nestlings, reducing competition among them when being fed (Slagsvold 1989).

As a bark nesting species, Brown Creeper (Davis 1978) has different selection criteria from the other species. It tends to select trees with large sections of loose bark to nest underneath, perhaps more frequently available on larger diameter trees. The species also prefers large diameter trees for foraging (Poulin et al. 2008) and choosing their nest site close to their food source could be advantageous.

\section{Decay}

Trees used for cavities on East Limestone Island were mostly in an advanced state of decay, with mean decay classes ranging from 4.5-5.0 (Figure 2). These trees would have decayed heartwood with relatively hard sapwood. Such trees may be more suitable as nest trees due to the decayed heartwood being soft enough for easy excavation, with an outer shell of relatively strong sapwood surrounding and protecting the nest cavity (Kilham 1971; Conner et al. 1976; Miller and Miller 1980). It is worth noting that the value of differing decay states of different species of trees is not adequately represented by the BC Tree Classification System (cf., Guy and Manning 1995). Trees may have a similar appearance but be harder or softer depending on their location. The location could be subject to different, perhaps stronger winds, or different climatic conditions, all of which would give the tree a different appearance, hence a different decay class.

\section{Cavity orientation}

Orientation was measured to understand nest site selection relative to microclimate. The orientation of Red-breasted Sapsucker cavity entrances was not random, perhaps because they attempt to regulate nest microclimate by orienting their nest entrances away from the prevalent southeast winds, which bring the heaviest rainfall to the island. In addition, the topography of the island allows for winds from this direction to be funneled into the interior of the island, strengthening its effect and perhaps strengthening the effect of cavity orientation. The apparent lack of preferred cavity orientation among other species may be a result of small sample size. Additional research is needed for Saw-whet Owl, as well as Northern Flicker and Red-breasted Nuthatch to shed further light on the nest site preferences of these species.

\section{Timing of breeding}

All of our nesting dates fell within the ranges indicated by Campbell et al. $(1990,1997)$ for individual species. However, Campbell et al. (1990, 1997) indicated a longer season (early May to end of July) for all species found on East Limestone Island. It appears that breeding on East Limestone Island varies little among species, with all initiating incubation in the first half of May, and most nesting completed by the end of June. One exception was the case of Red-breasted Sapsucker in 1999, when median fledging was six days later than in the next latest year. Breeding of open nesting species was later and less successful in 1999 because of low temperatures associated with a strong La Niña event (Gaston et al. 2005) and this may also have caused the late breeding of the sapsuckers. 


\section{Conclusion}

This 29-year study has provided insights into the significant characteristics of nest sites created or used by cavity-nesting birds on a small island in Haida Gwaii. The results of this work suggest that a rich diversity and healthy populations of cavity-nesting species can be supported on small islands with intact mature forests. The predominance of Red-breasted Sapsucker, a primary excavator, over other hole-nesting species, suggests that suitable holes are probably abundant for secondary species, such as chickadees and nuthatches, both of which used old sapsucker holes on occasion. On the mainland, cavity nests are found in a greater variety of trees, often in live deciduous trees at much lower heights. In future, when surveys are conducted on small islands it is important that attention is paid to the upper parts of large snags to ensure that cavity nests are not overlooked. Our results support the proposal that the protection of large old snags within northwest coastal forest ecosystems is essential to providing a healthy community of cavity-nesting birds (Cockle et al. 2011).

\section{Author Contributions}

Writing - Conceptualization \& Field Work Design: A.G., K.M., J.S.; Field Work Oversight: K.M., J.S., N.P.; Data Analysis \& Original Draft: N.P. \& A.G.; Writing - Review \& Editing: all authors.

\section{Acknowledgements}

We thank Colin French and Andrea Lawrence for initiating this project and all the board members, science advisors, volunteers, and employees with Laskeek Bay Conservation Society who contributed to it through the past 29 years, as well as all those who have supported the continuing efforts of the society. We would also like to thank the Haida Nation and the Province of British Columbia for their support of Laskeek Bay Conservation Society.

\section{Literature Cited}

Aitken, K.E.H., and K. Martin. 2007. The importance of excavators in hole-nesting communities: availability and use of natural tree holes in old mixed forests of western Canada. Journal of Ornithology 148 (Suppl. 2): S425-S434. https://doi.org/10.1007/s10336-007-0166-9

Banner, A., W.H. MacKenzie, J. Pojar, A. MacKinnon, S.C. Saunders, and H. Klassen. 2014. A field guide to ecosystem classifications and identification for Haida Gwaii. Land Management Handbook 68. BC Forests, Lands and Natural Resource Operations, Victoria, British Columbia, Canada.

Campbell, R.W., N.K. Dawe, I. McTaggart-Cowan, J.M. Cooper, G.W. Kaiser, and M.C.E. McNall. 1990. The Birds of British Columbia, Volume 2. University of British Columbia Press, Vancouver, British Columbia, Canada.
Campbell, R.W., N.K. Dawe, I. McTaggart-Cowan, J.M. Cooper, G.W. Kaiser, M.C.E. McNall, and G.E.J. Smith. 1997. The Birds of British Columbia, Volume 3. University of British Columbia Press, Vancouver, British Columbia, Canada.

Carlson, A., U. Sandström, and K. Olsson. 1998. Availability and use of natural tree holes by cavity-nesting birds in a Swedish deciduous forest. Ardea 86: 109-119.

Cockle, K.L., K. Martin, and T. Wesolowski. 2011. Woodpeckers, decay, and the future of cavity-nesting vertebrate communities worldwide. Frontiers in Ecology and the Environment 9: 377-382. https://doi. org/10.1890/110013

Conner, R.N. 1975. Orientation of entrances to woodpecker nest cavities. Auk 92: 371-374. https://doi.org/10.23 $07 / 4084566$

Conner, R.N., O.K. Miller, Jr., and C.S. Adkisson. 1976. Woodpecker dependence on trees infected by fungal heart rots. Wilson Bulletin 88: 575-581.

Davis, C.M. 1978. A nesting study of the Brown Creeper. Living Bird 17: 237-263.

Gaston, A.J., J.-L. Martin, and S. Allombert. 2005. Sea surface temperatures mediated by the El Niño-Southern Oscillation affect birds breeding in temperate coastal rain forests. Avian Conservation and Ecology 1: 4. Accessed 12 March 2019. http://www.ace-eco.org/vol1/iss 1/art4/.

Golumbia, T.E., L. Bland, K. Moore, and P. Bartier. 2008. History and current status of introduced vertebrates on Haida Gwaii. Pages 8-31 in Lessons from the Islands: Introduced Species and What They Tell Us about How Ecosystems Work. Proceedings from the 2002 Research Group on Introduced Species Symposium. Canadian Wildlife Service, Environment Canada, Ottawa, Ontario, Canada.

Guy, S., and T. Manning. 1995. Wildlife/danger tree assessor's course workbook. Canada-British Columbia Partnership Agreement on Forest Resource Development. Ministry of Forests, Victoria, British Columbia, Canada.

Hammer, Ø., D.A.T. Harper, and P.D. Ryan. 2001. PAST: paleontological statistics software package for education and data analysis. Palaeontologia Electronica 4: 4 pp.

Inouye, D.W. 1976. Nonrandom orientation of entrance holes to woodpecker nests in aspen trees. Condor 78: 101-102. https://doi.org/10.2307/1366924

Kilham, L. 1971. Reproductive behavior of yellow-bellied sapsuckers I. Preference for nesting in Fomes-infected aspens and nest hole interrelations with flying squirrels, raccoons, and other animals. Wilson Bulletin 83: 159-171.

Li, P., and T.E. Martin. 1991. Nest-site selection and nesting success of cavity-nesting birds in high elevation forest drainages. Auk 108: 405-418.

Martin, K.L., K.E. Aitken, and K.L. Wiebe. 2004. Nest sites and nest webs for cavity-nesting communities in interior British Columbia, Canada: nest characteristics and niche partitioning. Condor 106: 5-19. https://doi. org/10.1093/condor/106.1.5

Martin, J.L., S. Allombert, and A.J. Gaston. 2008. The effects of deer and squirrels on forest birds: community structure, population density, and reproduction. Pages 
93-99 in Lessons from the Islands: Introduced Species and What They Tell Us about How Ecosystems Work. Proceedings from the Research Group on Introduced Species 2002 Symposium. Canadian Wildlife Service, Environment Canada, Ottawa, Ontario, Canada.

Martin, K.L., and J.M. Eadie. 1999. Nest webs: a community-wide approach to the management and conservation of cavity-nesting forest birds. Forest Ecology and Management 115: 243-257. https://doi.org/10.1016/ s0378-1127(98)00403-4

Martin, J.L., and M. Joron. 2003. Nest predation in forest birds: influence of predator type and predator's habitat quality. Oikos 102: 641-653. https://doi.org/10. 1034/j.1600-0706.2003.12040.x

Maziarz, M., and T. Wesolowski. 2013. Microclimate of tree cavities used by Great Tits (Parus major) in a primeval forest. Avian Biology Research 6: 47-56. https:// doi.org/10.3184/175815513x13611994806259

McClelland, B.R., and S.S. Frissell. 1975. Identifying forest snags useful for hole-nesting birds. Journal of Forestry 73: 414-417.

Miller, E., and D.R. Miller. 1980. Snag use by birds. Pages 337-356 in Management of western forests and grasslands for nongame birds. Workshop proceedings, Salt Lake City, Utah, 11-14 February 1980. Technical coordinator R.M. DeGraff. US Forest Service General Technical Report. INT-86, Ogden, Utah, USA.

Newton, I. 1994. The role of nest sites in limiting the numbers of hole-nesting birds: a review. Biological Conservation 70: 265-276. https://doi.org/10.1016/0006-32 07(94)90172-4

Nilsson, S.G. 1984. The evolution of nest-site selection among hole-nesting birds: the importance of nest predation and competition. Ornis Scandinavica 15: 167-175. https://doi.org/10.2307/3675958

O'Connor, R.J. 1978. Nest-box insulation and the timing of laying in the Wytham woods population of great tits Parus major. Ibis 120: 534-537. https://doi.org/10.1111/ j.1474-919X.1978.tb06822.x

Pojar, J., and A. MacKinnon. 1994. Plants of the Pacific Northwest Coast. Lone Pine Publishing, Vancouver, British Columbia, Canada.

Poulin, J.F., M.A. Villard, M. Edman, P.J. Goulet, and A.M. Eriksson. 2008. Thresholds in nesting habitat requirements of an old forest specialist, the Brown Creeper (Certhia americana), as conservation targets. Biological Conservation 141: 1129-1137. https://doi.org/ 10.1016/j.biocon.2008.02.012

R Core Team. 2017. R: a language and environment for sta- tistical computing. R Foundation for Statistical Computing, Vienna, Austria.

Raphael, M.G., and M. White. 1984. Use of snags by cavity-nesting birds in the Sierra Nevada. Wildlife Monographs 86: 3-66.

Rasmussen, J.L., S.G. Sealy, and R.J. Cannings. 2008. Northern Saw-whet Owl (Aegolius acadicus), The Birds of North America Version 2.0. Cornell Lab of Ornithology, Ithaca, New York, USA. Accessed 9 March 2019. https://birdsna.org/Species-Account/bna/ species/nswowl.

Scott, V.E., K.E. Evans, D.R. Patton, and C.P. Stone. 1977. Cavity-nesting birds of North American forests (No. 511). Forest Service, US Department of Agriculture, Washington, DC, USA.

Slagsvold, T. 1989. On the evolution of clutch size and nest size in passerine birds. Oecologia 79: 300-305. https:// doi.org/10.1007/BF00384308

Steeger, C., and J. Dulisse. 2002. Characteristics and dynamics of cavity-nest trees in southern British Columbia. Pages 275-289 in Proceedings of the symposium on the ecology and management of dead wood in western forests. Edited by W.F. Laudenslayer, P.J. Shea, C.P. Witherspoon, and T.E. Lisk. USDA Forest Service, General Technical Report, PSW-GTR-181, Albany, California, USA.

Stockton, S.A., S. Allombert, A.J. Gaston, and J.L. Martin. 2005. A natural experiment on the effects of high deer densities on the native flora of coastal temperate rain forests. Biological Conservation 126: 118-128. https://doi.org/10.1016/j.biocon.2005.06.006

Vaillancourt, M.A., P. Drapeau, S. Gauthier, and M. Robert. 2008. Availability of standing trees for large cavity-nesting birds in the eastern boreal forest of Québec, Canada. Forest Ecology and Management 255: 2272-2285. https://doi.org/10.1016/j.foreco.2007.12.036

Van Balen, J.H. 1984. The relationship between nest-box size, occupation and breeding parameters of the Great Tit Parus major and some other hole-nesting species. Ardea 72: 163-175.

Von Haartman, L. 1957. Adaptation in hole-nesting birds. Evolution 11: 339-347. https://doi.org/10.1111/j.1558-56 46.1957.tb02902.x

Wesolowski, T. 2002. Anti-predator adaptations in nesting marsh tits Parus palustris: the role of nest-site security. Ibis 144: 593-601. https://doi.org/10.1046/j.14 74-919x.2002.00087.x

Received 30 April 2019

Accepted 24 December 2019 
APPENDIX 1. Incubation and fledging periods used in estimating dates of clutch completion for species with 10 or more records.

\begin{tabular}{|c|c|c|c|}
\hline Species & Incubation period (days) & Fledging period (days) & Reference \\
\hline $\begin{array}{l}\text { Hairy Woodpecker } \\
\text { (Dryobates villosus) }\end{array}$ & 13 & 29 & Jackson et al. 2018 \\
\hline $\begin{array}{l}\text { Red-breasted Sapsucker } \\
\text { (Sphyrapicus ruber) }\end{array}$ & 14 & 27 & Walters et al. 2014 \\
\hline $\begin{array}{l}\text { Chestnut-backed Chickadee } \\
\text { (Poecile rufescens) }\end{array}$ & 13 & 20 & Dahlsten et al. 2002 \\
\hline $\begin{array}{l}\text { Brown Creeper } \\
\text { (Certhia americana) }\end{array}$ & 15 & 17 & Poulin et al. 2013 \\
\hline
\end{tabular}

\section{Literature Cited}

Jackson, J.A., H.R. Ouellet, and B.J. Jackson. 2018. Hairy Woodpecker (Dryobates villosus), Version 1.1. In The Birds of North America. Edited by P.G. Rodewald. Cornell Lab of Ornithology, Ithaca, New York, USA. https://doi.org/10.2173/bna.haiwoo.01.1

Dahlsten, D.L., L.A. Brennan, D.A. McCallum, and S.L. Gaunt. 2002. Chestnut-backed Chickadee (Poecile rufescens), Version 2.0. In The Birds of North America. Edited by A.F. Poole and F.B. Gill. Cornell Lab of Ornithology, Ithaca, New York, USA. https://doi.org/10. 2173/bna. 689
Poulin, J.F., É. D'Astous, M. Villard, S.J. Hejl, K.R. Newlon, M.E. McFadzen, J.S. Young, and C.K. Ghalambor. 2013. Brown Creeper (Certhia americana), Version 2.0. In The Birds of North America. Edited by A.F. Poole. Cornell Lab of Ornithology, Ithaca, New York, USA. https://doi.org/10.2173/bna.669

Walters, E.L., E.H. Miller, and P.E. Lowther. 2014. Redbreasted Sapsucker (Sphyrapicus ruber), Version 2.0. In The Birds of North America. Edited by A.F. Poole. Cornell Lab of Ornithology, Ithaca, New York, USA. Accessed 9 March 2019. https://birdsna.org/SpeciesAccount/bna/species/rebsap. 